\title{
Peruvian Children's Folk Taxonomy of Marine Animals
}

\author{
José Pizarro-Neyra ${ }^{1}$ \\ Author Address: ${ }^{1}$ Proyecto Nuestro Medio Ambiente Marino, Perú josepizarroneyra@gmail.com
}

Received: June $18^{\text {th }} 2011$

Volume 2:50-57

Published: September 9th 2011

(C) 2011 Society of Ethnobiology

\begin{abstract}
Free listing was used to obtain names of marine animals from 234 Peruvian children with families involved in fishing activities. They live in the fishing towns of Vila-vila, Morro Sama and Ilo, located in Southern Peru. Fishes, birds and the category "other marine animal" were used for the classification of marine fauna by children. The group of 6-8 year-olds shows a mean frequency of 19.7 names per child, while the group of 9-11 year-olds shows a mean frequency of 25.7 names per child. Folk species of fish is the most frequently recorded category with a predominance of coastal species and with a mean frequency of 7.56 and 11.51 names per child for the groups of 6-8 year-olds and 9-11 year-olds, respectively. In contrast, bird names are less frequently recorded in the lists. Some bird and mollusc names have lexical under-differentiation at a generic level and apparently have lower cultural significance than fish. Children's classification in different levels of organization is evidence of a folk biology. The folk taxonomy of marine animals could be influenced by the lesser cognitive development of younger children and the ecological salience of some species. Some species with coastal habitat exhibit a high dominance index of folk names. Cultural transmission of knowledge about birds could be failing due to the recent occupancy of the study sites by migratory people and the sexual division of work in the children's families.
\end{abstract}

Key Words: folk taxonomy, ecological salience, cognitive development, marine animals, children, fishing, southern Peru

\section{Introduction}

Children's folk biology has been studied recently in Latin America, however, the folk taxonomy built by children is lesser known. According to $\mathrm{Au}$ and Romo (1999), if children make a distinction between biological and non-biological species, they demonstrate a folk biology. Ross et al. (2002) argue that rural children from non-western cultures who are exposed to nature make use of relationships between organisms to explain biological phenomena. This is evidence of the existence of children's folk biology. Fish are predominant in the study of the folk biology of marine animals in South America. Paz and Begossi (1996) studied the nomenclature, classification and ethnoecology of Brazilian marine fish among small-scale fishermen, but no children were included in their work.

The ethnobiological classification of life-form taxa is influenced by utilitarian or perceptual factors, but folk generic categories have mainly perceptual salience (Berlin 1992). Their generalization implies that there exists a predominance of perceptual factors influencing folk taxonomy of children. But, according to Markman (1989), little children tend to use thematic relationships rather than taxonomic similarity for the categorization of objects. This is in concordance with the lesser cognitive development in children under six years. In this sense, Johnson \& Carey (1988) affirm that children finish acquiring knowledge of animals around age ten.

Another aspect linked with folk taxonomy is the universality of the categories. Brown (1979) suggested the universality of the categories "fish," "mammals," "reptile," "bird" and "WUG." The acquisition of these zoological life-forms by children is complete at age eight. In this article, the folk taxonomy used by rural children on the Peruvian southern coast is examined. I search organization levels of the marine animals and the reasons that would explain the Peruvian children's classification system. This information is considered important for the management and conservation of marine habitats (Drews 2005).

\section{Methods}

Study zone-The fishing villages of Vila-vila $\left(18^{\circ} 07^{\prime} \mathrm{S}\right.$ $70^{\circ} 36^{\prime} \mathrm{W}$ ) and Morro Sama (18 ${ }^{\circ} \mathrm{S} 70^{\circ} 54^{\prime} \mathrm{W}$ ) are located in the Department of Tacna and the port of Ilo $\left(17^{\circ} 38^{\prime} \mathrm{S} 71^{\circ} 20^{\prime} \mathrm{W}\right)$ is located in the Department of Moquegua. Tacna and Moquegua are the southernmost departments of Peru. Fishing is the main activity in the localities under study. The exploitation of marine resources for the fish meal industry is a important to the national economy. In Tacna and Moquegua fishermen practice mainly small-scale fishing. 
Table 1. Number of genera and species of marine animals named per Peruvian child.

\begin{tabular}{l|l|l|l}
\hline Age Group & $\begin{array}{l}\text { Fish } \\
\text { taxa }\end{array}$ & Bird taxa & $\begin{array}{l}\text { Other marine } \\
\text { animal taxa }\end{array}$ \\
\hline $6-8$ yrs old & 7.56 & 3.79 & 8.125 \\
\hline $9-11$ yrs old & 11.51 & 3.95 & 10.24 \\
\hline
\end{tabular}

The children-All children studied were students at the primary schools in Vila-vila, Morro Sama and Ilo whose families were involved in the fishing industry. The informants were 234 children between the ages of 6 and 11 divided in two groups: ages $6-8(\mathrm{~N}=102)$ and ages $9-11(\mathrm{~N}=132)$.

The list-Children were invited to recall and write the maximum quantity of names of marine animals in twenty minutes. They created their lists on forms comprised of three columns corresponding to the following categories: "marine fish," "marine bird" and the category "other marine animal." This last category covers all others marine animals and contains less diversity than fish and birds in the students' natural surroundings. The form was developed with sufficient space to write approximately twenty names in each column. The listing exercise was administered to children during school hours in July and November 2006 and in June 2007.

Analysis-The supplementary table (end of the document) summarizes marine animals named by the Peruvian children who were interviewed. The scientific names and the habitat of the folk species were obtained from Chirichigno and Vélez (1998) for fish, Vizcarra (2006) and Schulenberg et al. (2007) for birds, Jefferson et al. (1993) for marine mammals and Paredes et al. (1988) for marine invertebrates. In case of doubt about the correspondence between folk names and scientific species, names were clarified during classes in the schools, where students identified the organisms after observing photographs. This was needed in the cases of marine turtles, mollusks, fur seals, gulls, cormorants, and some fish such as pampano (Trachinotus paitensis Carangidae Cuvier). The purpose of Table 1 is to identify the lexical differentiation of species and their cultural importance. The marine animal identified is indicated by the folk category mentioned by children for each one. The habitat of each species obtained from the literature serves as an indicator of ecological salience when these species appears more frequently in the lists. The measurement of this frequency was calculated by a dominance index using the formula

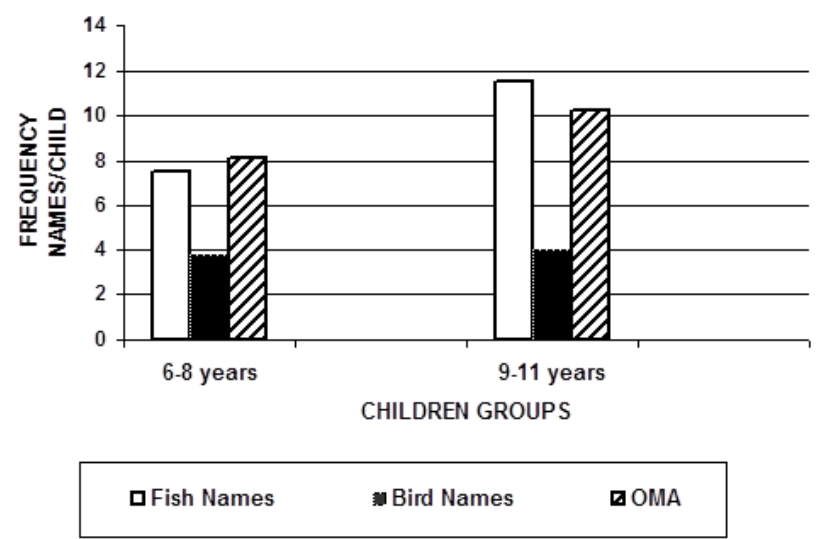

Figure 1. Frequency of marine animals names used per child.

$\mathrm{D}=\left(\sum \mathrm{L}\right) / \mathrm{T} . \mathrm{L}=$ lists containing the name of a species. $\mathrm{T}=234$ examined lists. The species with higher values of $\mathrm{D}$ and usually caught near the shore would indicate species with ecological salience.

\section{Results \& Discussion}

Children wrote 58 folk names of marine animals in all the lists. Fish was the most frequently mentioned lifeform, comprising $55 \%$ of the total folk taxa. Names of terrestrial animals, such as dog, cat and dove appeared in some lists, but these animals are not considered in this study. Many lists show names at generic level, such as pajarito (little bird), ave marina (seabird), pescado (fish), pescado chico and pescado grande (little and big fish, respectively). These names do not appear in the analysis of folk names (Supplementary Table, end of document). A total of 5380 mentions of marine animals were counted in all the lists. Table 1 lists only 4675 mentions of folk taxa with a dominance index $>0.05$.

According to the results (Table 1), most marine animals live in coastal habitats, but only a few animals exhibit ecological salience, with a dominance index $>$ 0.50. This is the case for Peruvian pelicans (Pelecanus thagus Pelecanidae Molina) ( $\mathrm{D}=0.84)$, Humboldt penguins (Spheniscus bumboldtii Spheniscidae Meyen) $(\mathrm{D}=0.78$ ), sea gulls (mainly Larus belcheri Laridae Vigors, L. modestus Laridae Tschudii and $L$. dominicanus Laridae Lichtenstein) $(\mathrm{D}=0.79)$, cormorants (Phalacrocorax spp. Phalacrocoracidae Brisson) $(\mathrm{D}=0.56)$, marine fur seals (Otaria byronia Otariidae Shaw) $(\mathrm{D}=0.78)$, pejerrey (Odonthesthes regia Atherinopsidae Hildebrand) $(\mathrm{D}=$ 0.54), and lapa (Fissurella spp. Fissurellidae) $(\mathrm{D}=0.69)$.

The group of 6-8 year-olds old shows a mean frequency of 19.7 names per child, while the group of 9-11 year-olds presented 25.7 names per child (Table 
1). The category of fish was most often mentioned in the lists with frequencies varying between 7.5 and 11.5 names per child (Figure 1). Fish are mentioned mainly using the specific level when perceptual salience is present such as in the case of pintacha (Cheilodactylus variegatus Cheilodactylidae Valenciennes), pejesapo (Syciases sanguineus Gobiesocidae M. et T.) and Diamante (Isurus oxyrbinchus Lamnidae Rafinesque). These folk names exhibit one-to-one correspondence with scientific species which indicates cultural significance. Indeed, these are target species for local fishermen according to Estrella et al. (2006).

The pelagic species known as perico (Coryphaena hppurus Coryphaenidae L.) is easily recognized by children due to their perceptual salience and because it is a species caught and consumed in the area at low prices. However, coastal species of fish are predominant in the lists. Coastal fish are considered target species of artisanal fishery in Tacna and Moquegua according to Estrella et al. (2006). The fish mentioned by the children have cultural salience as sources of food. Sethalaphruk and Price (2007) observed that children's knowledge of animals used as food resources is mediated by the consumption or sale of them. In addition, some children in Vila-vila and Morro Sama use fish as bait for shore fishing, as in the case of michi (Chromis crusma Cuvier and Valenciennes) (Figure 2). In this case, boys that fish use other criteria besides just perceptual characteristics for the recognition of species. Boster and Johnson (1989) affirm that some novice fishers recognize fish species using morphological appearance because knowledge of utility and behaviour requires cultural transmission and more experience.

In contrast, marine birds are the category with fewer mentions in the children's lists with a mean frequency of 3.9 names per child. This is relevant because Peru is a country that lacks diversity of bird species (Schulenberg 2007). On the coast of Tacna, there are only 144 reported species of birds (Vizcarra, 2006). Following the theory of Hunn (1999), the birds mentioned are probably species with higher ecological salience. The species mentioned in the childrens' lists are: Peruvian pelican or buacacho (Pelecanus thagus Molina), guanay (Phalacrocorax bouganvilliii Phalacrocoracidae Lesson), piquero (Sula variegata Sulidae Tschudi), and the Humboldt penguin or pinguino. Generic names mentioned were: patillo (corresponding to cormorants such Phalacrocorax bouganvillii Phalacrocoracidae Lesson and Phalacrocorax brasiliensis Phalacrocoracidae Gmelin) and gaviota or perica corresponding to at least the three species of Larus

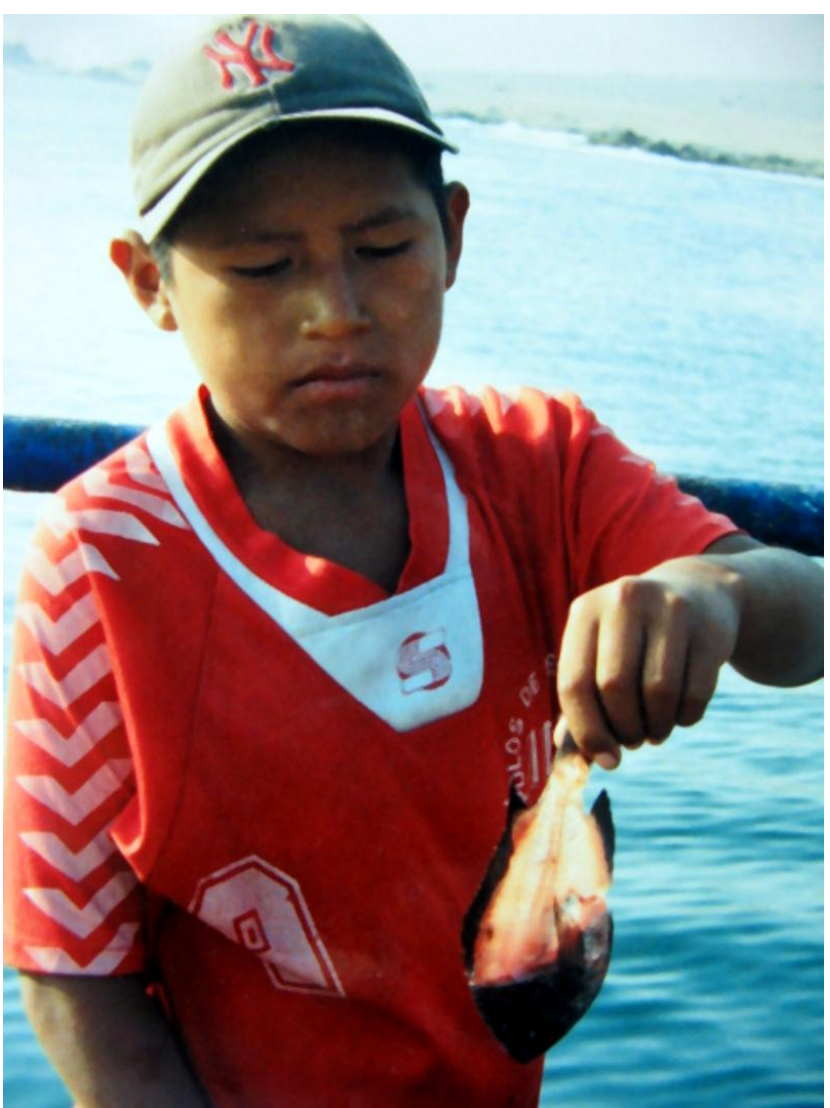

Figure 2. Peruvian child holding a michi (Chromis crusma) to be used as bait.

gulls listed above. Following Martin (1995), species that are less important culturally are usually underdifferentiated. In this sense, the lexical underdifferentiation of some marine birds in the lists indicates a lower cultural importance of marine birds.

The majority of marine birds mentioned can be found near ports, searching through garbage or fishing nets for food. All bird species have coastal habitats and are commonly found in the area (Table 1). Perhaps the low number of names for small birds such as sandpipers and lesser terns, which are abundant in the area, is due to their size. These birds' small size may not allow children and their parents to recognize details for species identification.

The cultural transmission of local knowledge about avifauna could be lacking for at least two reasons. First, some children's families are migratory people from the Andes, with limited ecological knowledge of marine resources. Migrants represent $30 \%$ of the total population of the Departments of Tacna and Moquegua, (INEI 2008). Secondly, a mother's knowledge of marine fauna could be scarce. In this 
situation, a child's limited knowledge of birds could be due to the amount of time spent with her mother.

The gender division of work in Peruvian fishing villages deters women from working on boats during fishing activities. According to Estrella et al. (2006), $10 \%$ of artisanal fishers in Tacna are women who only participate in the harvest of mollusks or aid their husbands with net fishing along the shore. Women are not allowed to work on boats.

Therefore, women and children would not see the many bird species that men would see during fishing activities. In Berlin's (1981) ethno-ornithological study, women show less linguistic ability in the folk taxonomy of birds than men due to two factors: 1) a limited outcome of life experience in the hunting, and 2) no opportunity to observe entire birds because males remove all plumage before women prepare them for food. Children's knowledge about marine birds in our study zone could be lower probably because none of these types of birds are cooked and eaten by the fishermen families.

Some folk species from the category "other marine animals" do not correspond with the Linnean taxonomy. The cetaceans are classified as fish by $66 \%$ of the 6-8 year-olds and by $43 \%$ of the $9-11$ year-olds. According to Souza and Begossi (2007), the cultural transmission from elders to younger fishermen could play a role in the identification of cetaceans as fish in other parts of South America.

Fish and cetaceans such as porpoises and dolphins share morphological attributes (shape, fins) and could belong to the same group of animals in the taxonomies of little children. Markman (1989), explains that young children tend to acquire basic categorizing skills by maximizing the similarities between category members and minimizing the similarities between members of other categories. In addition, some students in Vila-vila and Morro Sama said that they ate porpoise meat in reference to chancho marino (Phocoena spinipinnis Phocoenidae Burmeister). This species is mentioned in their lists, and children that eat cetacean meat are using the utilitarian factor to group porpoises into the fish category. According to Van Waerebeek and Reyes (1994), this species suffers incidental capture in Vilavila and is used as bait in Ilo.

Sharks and sea horses are identified as "other marine animals" by $12 \%$ of the $6-8$ year olds. These folk names were not grouped within the fish category by the children, perhaps due to their dissimilarities with the previously learned fish prototype. The status of the sea horses in the folk taxonomy is unique. For example, the sea horse was not classified by any folk taxa by
Brazilian artisanal fishermen (Paz and Begossi 1996). Sharks, however, are well recognized as a taxonomical group by children, perhaps due to their cultural importance. Sharks are caught in southern Peru during the winter with longlines known as redes animaleras (nets for the animal), and fisherman call sharks el animal (the animal). In my experience, artisanal fishermen identify sharks as a different group of fish.

Additionally, the Humbolt penguin was classified as "other marine animals" by $8 \%$ of the $6-8$ year-olds. Trowbridge and Mintzes (1985) suggest that the penguins are not identified by children as birds due to their similarity with marine mammals and the fact that they do not fly.

Very few names of invertebrates were written within the category "other marine animals" considering the abundance of these organisms in the Peruvian sea. But some mollusks such as the gastropods exhibit under-differentiation of the folk species (Table 1). For instance, mollusks of the generic level lapa comprise at least two species not differentiated by children. This is evidence of moderate or low cultural significance of these species, probably due to how little they are used.

Finally, the classification of sessile invertebrates such "other marine animals" can be a problem for young children. Carey (1988) indicates that small children manage the concept "animal" as an entity with the capacity of "action." For this reason, it is possible that sessile animals such as mollusks were not included in the lists made by children aged 6-8 years.

\section{Conclusions}

The use of different levels of classification (life-forms, generic and specific) is evidence of the existence of folk taxonomy among children from the southern coast of Peru. Cetaceans were classified in the category "fish" by some children. The Humboldt penguin and some fish were also classified as "other marine animals" (neither fish nor birds) in order to differentiate from the previously learned prototype of fish and bird. "Marine birds" is the category less frequently mentioned, and some folk species present less cultural importance. Some mollusks and birds with lexical under-differentiation would be considered to have low cultural importance. In contrast, marine fish would be considered the category with higher cultural significance for the children. Cultural transmission about local ecological knowledge of marine resources is failing due to the recent migration of people from the Andes and by the gender division of work that leads to a lack of experience in fishing activities among women. The lower number of marine animal names recorded 
per child in the 6-8 year-old age group is most likely explained by the lower cognitive development of younger children.

\section{Acknowledgements}

Many thanks to students in San Pedro and Morro Sama schools in Tacna and to students children at Jorge Basadre, Daniel Becerra, L. Conde and Avelino Cáceres schools in Ilo. Maureen MacCarthy aided with translation of this report.

\section{References Cited}

Au, T. K. and L. Romo. 1999. Mechanical Causality in Children's Folkbiology. In Folkbiology, edited by D. C.

Medin and S. Atran, pp. 355-402. MIT Press, Cambridge.

Berlin, B. 1992. Ethnobiological Classification. Principles of Categorization of Plants and Animals in Traditional Societies. Princeton University Press, Princeton.

Berlin, B., J. S. Boster, and J. P. O’Neil. 1981. The Perceptual Bases of Ethnbiological Classification: Evidence from Aguaruna Jívaro Ornithology. Journal of Ethnobiology 1:95-108.

Boster, J. S. and J. C. Johnson. 1989. Form of Function: A Comparison of Expert and Novice Judgments of Similarity among Fish. American Anthropologist 91:866-889.

Brown, C. 1979. Folk-Zoological Life-Forms: Their Universality and Growth. American Anthropologist 81:791-817.

Carey, S. 1988. Conceptual Differences between Children and Adults. Mind and Language 3:167-181.

Chirichigno, N. and J. Vélez. 1998. Clave para Identificar Los Peces Marinos del Perú, Segunda edición. Instituto del Mar del Perú, Callao.

Drew, J. A. 2005. Use of Traditional Ecological Knowledge in Marine Conservation. Conservation Biology 19:1286-1293.

Estrella, C., G. Castillo, and J. Fernández. 2006. Encuesta Estructural de la Pesquería Artesanal Peruana. Regiones de Moquegua y Tacna. IMARPE-PRODUCEAECI, Callao.

Johnson, S. and S. Carey. 1998. Knowledge Enrichment and Conceptual Change in Folkbiology: Evidence from Williams Syndrome. Cognitive Psychology 37:156-200.

Hunn, E. 1999. Size as Limiting the Recognition of Biodiversity in Folkbiological Classifications: One of
Four Factors Governing the Cultural Recognition of Biological Taxa. In Folkbiology, edited by D.C. Medin and S. Atran, pp. 47-69. MIT Press, Cambridge.

INEI. 2008. Censos Nacionales 2007: XI de Población y VI de Vivienda. Resultados Definitivos. Tomo I. Dirección Nacional de Censos y Encuestas del Instituto Nacional de Estadística e Informática, Lima.

Jefferson, T. A., S. Leatherwood and M. A. Webber. 1993. Marine Mammals of the World. FAO Species Identification Guide. FAO, Rome.

Markman, E. M. 1989. Categorization and Naming in Children: Problems of Induction. MIT Press, Bradford Books, Cambridge.

Martin, G. J. 1995. Ethnobotany: A Methods Manual. Chapman and Hall, London, UK.

Paredes, C., J. Tarazona, E. Canahuire, L. Romero and O. Cornejo.1988. Invertebrados Macro.Bentónicos del Área de Pisco, Perú. In Recursos y Dinámica del Ecosistema de Afloramiento Peruano. Volúmen extraordinario, edited by H. Salzwedel and A. Landa, pp. 121-132. Boletín IMARPE, Callao.

Paz, V. A. and A. Begossi. 1996. Ethnoicthyiology of Gamboa Fishermen of Sepetiba Bay, Brazil. Journal of Ethnobiology 16:157-168.

Ross, N., D. L. Medin, J. D. Coley and S. Atran. 2003. Cultural and Experiential Differences in the Development of Folkbiological Induction. Cognitive Development 18:25-47.

Schulenberg, T. S., D. F. Stotz, D. L. Lane, J. P. O'Neill and T. A. Parker. 2007. Birds of Peru. Princeton University Press, Princeton.

Setalaphruk, C. and L. L. Price. 2007. Children's Traditional Ecological Knowledge of Wild Food Resources: A Case Study in a Rural Village in Northeast Thailand. Journal of Ethnobiology and Ethnomedicine 3:33. Doi:10.1186/1746-4269-3-33.

Souza, S. P. and A. Begossi. 2007. Whales, Dolphins or Fishes? The Ethnotaxonomy of Cetaceans in São Sebastião, Brazil. Journal of Ethnobiology and Ethnomedicine 3:9. Doi:10.1186/1746-4269-3-9.

Trowbridge, J. E. and J. Mintzes. 1985. Students' Alternative Conceptions of Animals and Animal Classification. School Science and Mathematics 85:304-316.

Van Waerebeek, K. and J. C. Reyes. 1994. Post-Ban Small Cetacean Takes off Peru: A Review. Report International Whaling Commission 15:503-519. 
Vizcarra, J. 2006. Aves de los Humedales de Ite y Alrededores. Biodiversidad y Conservación Integral (Colombia) 11:41-50.

\section{Biosketch}

Jose Pizarro-Neyra was born in Tacna, southern Peru. He is a researcher with interests in ethnobiology. In 2007 Jose began doing research among artisanal fishermen and their children, looking at the ethnotaxonomy of marine animals. He is a member of the Nuestro Medio Ambiente Marino project team.

Supplementary Table. Folk taxa and habitat of marine animals named by Peruvian children.

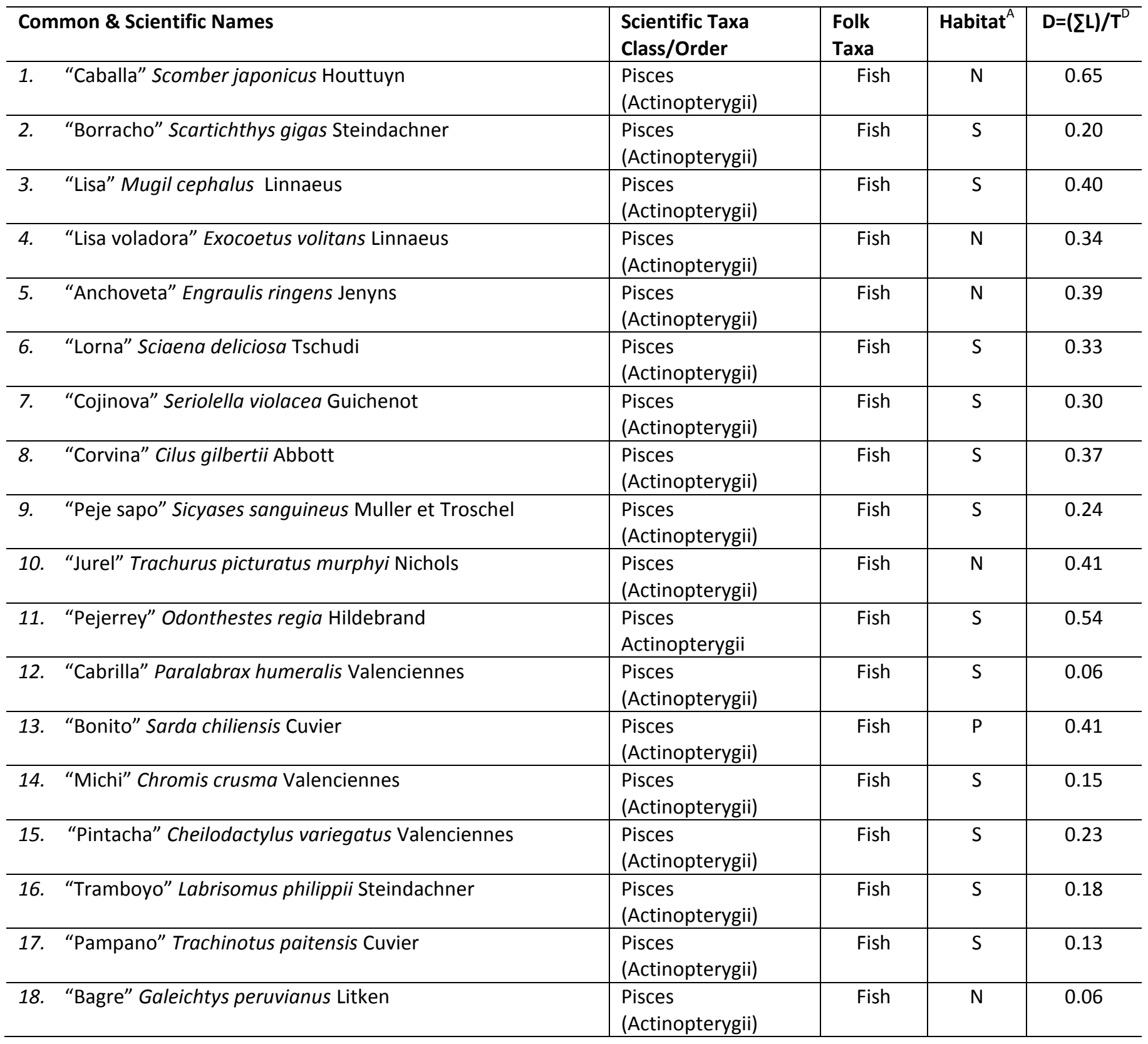




\begin{tabular}{|c|c|c|c|c|}
\hline 19. “Cabinza” Isacia conceptionis Cuvier & $\begin{array}{l}\text { Pisces } \\
\text { (Actinopterygii) }\end{array}$ & Fish & $\mathrm{N}$ & 0.63 \\
\hline 20. "Sargo" Anisotremus scapularis Tschudi & $\begin{array}{l}\text { Pisces } \\
\text { (Actinopterygii) }\end{array}$ & Fish & $\mathrm{S}$ & 0.13 \\
\hline 21. "Lenguado" Paralichtys adspersus Steindachner & $\begin{array}{l}\text { Pisces } \\
\text { (Actinopterygii) }\end{array}$ & Fish & $\mathrm{S}$ & 0.38 \\
\hline 22. "Tollo" Mustelus whithneyi Chirichigno & $\begin{array}{l}\text { Pisces } \\
\text { (Chondricthyes) }\end{array}$ & Fish & $\mathrm{S}$ & 0.14 \\
\hline 23. "Raya" Not identified at species level & $\begin{array}{l}\text { Pisces } \\
\text { (Chondricthyes) }\end{array}$ & Fish & $\mathrm{N}$ & 0.21 \\
\hline 24. "Tiburón" Not identified at species level & $\begin{array}{l}\text { Pisces } \\
\text { (Chondricthyes) }\end{array}$ & $\begin{array}{l}\text { Fish, } \\
\mathrm{OMA}^{\mathrm{B}, \mathrm{C}}\end{array}$ & $P$ & 0.34 \\
\hline 25. "Perico" Coryphaena hippurus Linnaeus & $\begin{array}{l}\text { Pisces } \\
\text { (Actinopterygii) }\end{array}$ & Fish & $\mathrm{P}$ & 0.73 \\
\hline 26. "Caballito de mar" Hippocampus ingens Girard & $\begin{array}{l}\text { Pisces } \\
\text { (Actinopterygii) }\end{array}$ & $\begin{array}{l}\text { Fish, } \\
\mathrm{OMA}^{\mathrm{B}}\end{array}$ & $\mathrm{N}$ & 0.18 \\
\hline 27. "Diamante" Isurus oxyrhinchus Rafinesque & $\begin{array}{l}\text { Pisces } \\
\text { (Chondricthyes) }\end{array}$ & Fish & $P$ & 0.37 \\
\hline 28. "Martillo" Sphyrna zygaena Linnaeus & $\begin{array}{l}\text { Pisces } \\
\text { (Chondricthyes) }\end{array}$ & Fish & $P$ & 0.11 \\
\hline 29. "Pelicano" Pelecanus thagus Molina & Aves & Bird & $P$ & 0.84 \\
\hline 30. "Pingüino" Spheniscus humboldti Molina & Aves & $\begin{array}{l}\text { Bird, } \\
\text { OMA }^{B}\end{array}$ & $\mathrm{~N}$ & 0.78 \\
\hline $\begin{array}{l}\text { 31. "Patillo"At least two species: Phalacrocorax brasiliensis } \\
\text { Gmelin and Phalacrocorax bouganvillii Lesson }\end{array}$ & Aves & Bird & $\mathrm{S}$ & 0.56 \\
\hline 32. "Guanay" Phalacrocorax bouganvillii Lesson & Aves & Bird & $S$ & 0.25 \\
\hline 33. "Piquero" Sula variegata Tschudi & Aves & Bird & $\mathrm{S}$ & 0.21 \\
\hline $\begin{array}{l}\text { 34. "Gaviota" \& "Perica” At least three species: Larus belcheri } \\
\text { Vigors, Larus dominicanus Lichtenstein and Larus modestus } \\
\text { Tschudi }\end{array}$ & Aves & Bird & $\mathrm{S}$ & 0.79 \\
\hline 35. "Pulpo" Octopus sp. & $\begin{array}{l}\text { Mollusca } \\
\text { (Cephalopoda) }\end{array}$ & OMA & $\mathrm{S}$ & 0.52 \\
\hline 36. “Pota” Dosidiscus gigas D'Orbigny & $\begin{array}{l}\text { Mollusca } \\
\text { (Cephalopoda) }\end{array}$ & OMA & $\mathrm{P}$ & 0.41 \\
\hline 37. "Ballena" Not identified at species level & Mammalia (Cetacea) & $\begin{array}{l}\text { OMA, } \\
\text { Fish }^{B}\end{array}$ & $P$ & 0.60 \\
\hline 38. "Orca" Orcinus orca Linnaeus & Mammalia (Cetacea) & $\begin{array}{l}\text { OMA, } \\
\text { Fish }^{B}\end{array}$ & $\mathrm{P}$ & 0.33 \\
\hline 39. "Delfín" Tursiops truncatus Montagu & Mammalia (Cetacea) & $\begin{array}{l}\text { OMA, } \\
\text { Fish }^{\text {B }}\end{array}$ & $P$ & 0.50 \\
\hline 40. "Chancho marino" Phocoena spinpinnis Burmeister & Mammalia (Cetacea) & $\begin{array}{l}\text { OMA, } \\
\text { Fish }^{B}\end{array}$ & $\mathrm{~N}$ & 0.25 \\
\hline $\begin{array}{l}\text { 41. "Lobo marino"Two species: Otaria byronia Shaw and } \\
\text { Arctocephalus australis Zimmerman }\end{array}$ & $\begin{array}{l}\text { Mammalia } \\
\text { (Carnivora) }\end{array}$ & OMA & $\mathrm{S}$ & 0.78 \\
\hline 42. "Chungungo" Lontra felina Molina & $\begin{array}{l}\text { Mammalia } \\
\text { (Carnivora) }\end{array}$ & OMA & $\mathrm{S}$ & 0.28 \\
\hline $\begin{array}{l}\text { 43. "Estrella de mar" At least two species: Stichaster striatus } \\
\text { Lamarck and Heliasther helianthus Lamarck }\end{array}$ & $\begin{array}{l}\text { Echinodermata } \\
\text { (Asteroidea) }\end{array}$ & OMA & $\mathrm{S}$ & 0.53 \\
\hline $\begin{array}{l}\text { 44. "Tortuga" At least two species: Caretta caretta Linnaeus } \\
\text { and Chelonia agassizi Bocourt }\end{array}$ & Reptilia (Testudines) & OMA & $P$ & 0.36 \\
\hline $\begin{array}{l}\text { 45. "Poto de mar" At least two species: Phymactis papillosa } \\
\text { Lesson and Phymantea pluvia Drayton }\end{array}$ & $\begin{array}{l}\text { Coelenterata } \\
\text { (Anthozoa) }\end{array}$ & OMA & $\mathrm{S}$ & 0.12 \\
\hline
\end{tabular}




\begin{tabular}{|c|c|c|c|c|}
\hline 46. "Choro" Aulacomya ater Molina & Mollusca (Bivalvia) & OMA & $\mathrm{s}$ & 0.33 \\
\hline 47. "Almeja" Prothotaca thaca Molina & Mollusca (Bivalvia) & OMA & $\mathrm{S}$ & 0.16 \\
\hline 48. "Chanque" Concholepas concholepas Bruguiére & $\begin{array}{l}\text { Mollusca } \\
\text { (Gastropoda) }\end{array}$ & OMA & $\mathrm{S}$ & 0.34 \\
\hline 49. "Muy-muy" Emerita analoga Stimpson & $\begin{array}{l}\text { Crustacea } \\
\text { (Decapoda) }\end{array}$ & OMA & $\mathrm{S}$ & 0.32 \\
\hline 50. "Macha" Mesodesma donacium Lamarck & Mollusca (Bivalvia) & OMA & $\mathrm{s}$ & 0.12 \\
\hline $\begin{array}{l}\text { 51. "Chiton" At least two species: Enoplochiton niger Barnes } \\
\text { and Chiton granosus Frembly }\end{array}$ & $\begin{array}{l}\text { Mollusca } \\
\text { (Gastropoda) }\end{array}$ & OMA & $\mathrm{s}$ & 0.15 \\
\hline $\begin{array}{l}\text { 52. "Caracol" At least two species: Thais chocolate Duclos and } \\
\text { Tegula atra Lesson }\end{array}$ & $\begin{array}{l}\text { Mollusca } \\
\text { (Gastropoda) }\end{array}$ & OMA & $\mathrm{s}$ & 0.28 \\
\hline 53. "Erizo negro" Tetrapygus níger Molina & $\begin{array}{l}\text { Echinodermata } \\
\text { (Echinoidea) }\end{array}$ & OMA & $\mathrm{s}$ & 0.30 \\
\hline $\begin{array}{l}\text { 54. "Lapa" At least two species: Fissurella crassa Lamarck and } \\
\text { Fissurela cumingsi Reeve }\end{array}$ & $\begin{array}{l}\text { Mollusca } \\
\text { (Gastropoda) }\end{array}$ & OMA & $\mathrm{s}$ & 0.69 \\
\hline 55. "Jaiva" Cancer setosus Molina & $\begin{array}{l}\text { Crustacea } \\
\text { (Decapoda) }\end{array}$ & OMA & $\mathrm{s}$ & 0.43 \\
\hline $\begin{array}{l}\text { 56. "Araña de mar" At least two species: Grapsus grapsus } \\
\text { Linnaeus and Geograpsus lividus Milne Edwards }\end{array}$ & $\begin{array}{l}\text { Crustacea } \\
\text { (Decapoda) }\end{array}$ & OMA & $\mathrm{s}$ & 0.17 \\
\hline 57. "Camarón" Cryphiops caementarius Molina & Crustacea (Natantia) & OMA & $\mathrm{S}$ & 0.22 \\
\hline 58. "Cangrejo" Ocypode gaudichaudii Milne Edwards and Lucas & $\begin{array}{l}\text { Crustacea } \\
\text { (Decapoda) }\end{array}$ & OMA & $\mathrm{S}$ & 0.16 \\
\hline
\end{tabular}

${ }^{A}$ Habitat: $\mathrm{S}=$ Shore, $\mathrm{N}=$ Neritic, $\mathrm{P}=$ Pelagic

${ }^{B}$ Classified by some children as this folk taxa

COther Marine Animals

${ }^{\mathrm{D}} \mathrm{D}=$ dominance index. $\mathrm{L}=$ lists containing the name of a species. $T=$ the number of lists examined. The higher the $D$ value, the greater the ecological salience. 